\title{
Argon plasma coagulation
}

\author{
Argon-Plasma Koagulation
}

\begin{abstract}
Argon Plasma Coagulation (APC) is an application of gas discharges in argon in electrosurgery, which is increasingly used especially in endoscopy. The major application fields are haemostasis, tissue devitalization and tissue reduction.

This review describes the physics and technology of electrosurgery and APC. Some characteristics of the argon discharge are shown and discussed, and thermal effects in biological tissue are described. Subsequently, examples of medical applications are given.
\end{abstract}

\section{Zusammenfassung}

Argon-Plasma Koagulation (APC) ist eine Anwendung von Gasentladungen in Argon in der Elektrochirurgie, die besonders in der Endoskopie zunehmend eingesetzt wird. Die wichtigsten Anwendungsgebiete sind Hämostase sowie Devitalisierung und Reduzierung von Gewebe.

Dieser Übersichtsartikel beschreibt die Physik und Technologie von Elektrochirurgie und APC. Charakteristiken der Argonentladung werden vorgestellt und diskutiert, und thermische Effekte in biologischem Gewebe werden beschrieben. Anschließend werden Beispiele medizinischer Anwendungen vorgestellt.

\section{Introduction}

Gas discharges in argon find a growing field of application in electrosurgery, where they are used to induce mostly superficial thermal effects on tissue in a non-contact manner. The corresponding technique is called Argon Plasma Coagulation (APC). First introduced in open surgery in the late 1970s [1], it was adapted for use in endoscopy in 1991 [2], [3] and has become the most commonly used endoscopic coagulation technique.

In the following sections, the basics of electrosurgery are briefly reviewed. The generation, electrical characteristics and the application of argon plasma in electrosurgery are then presented, including medical application examples.

\section{Basics of electrosurgery}

Electrosurgery is the application of an alternating current (AC) to biological tissue in order to induce a thermal effect through ohmic heating, which is used to selectively destroy the tissue. In the following sections, different kinds of thermal effects and the method of tissue heating will be presented in more detail.

\subsection{Thermal effects in biological tissue}

Heating of biological tissue can induce different effects which depend not only on the reached temperature, but also on the rate and duration of heating [4], [5].

For human tissue, at temperatures below $40^{\circ} \mathrm{C}$, no irreversible cellular damage occurs in general. The phenomena occurring for temperatures between 40 and $50^{\circ} \mathrm{C}$ are summarized under the term of hyperthermia. Changes at cellular membranes and molecular structures set in, and the interstitial fluid may increase due to water secretion by the cells (oedema formation). Depending on the duration of heating, those changes may still be reversible, but after several minutes, the tissue may begin to die. At higher temperatures, the cells are irreversibly damaged already after a few seconds. Between 60 and $80^{\circ} \mathrm{C}$, denaturation of the internal proteins occurs first. This process is called coagulation and leads to cell death (necrosis). The intercellular proteins then also coagulate and transform to gelatine. In addition, the cell membranes are destroyed since they contain a large proportion of proteins. At $100^{\circ} \mathrm{C}$, the evaporation of the cellular liquid sets in. Additional heat is now converted to energy of evaporation. The vapour pressure leads to mechanical destruction of the tissue. Depending on the rate of the heat dissipation, the evaporation takes place slowly, leading to dessication, or violently, leading to vaporization of the tissue. Only when all liquid has evaporated, the 
temperature can raise beyond $100^{\circ} \mathrm{C}$, and the remaining material may burn, inducing carbonization. Table 1 shows an overview over the temperatures and their effects.

Table 1: Effects of temperature in biological tissue

\begin{tabular}{|l|l|}
\hline $\begin{array}{l}\text { Temperature } \\
\text { in tissue }\end{array}$ & Effect \\
\hline$<40^{\circ} \mathrm{C}$ & None \\
\hline $40-50^{\circ} \mathrm{C}$ & $\begin{array}{l}\text { Hyperthermia: changes in cellular } \\
\text { membrane and internal molecular } \\
\text { structures, oedema formation } \\
\text { Time-dependent cell death } \\
\text { (necrosis) and devitalization }\end{array}$ \\
\hline $60-80^{\circ} \mathrm{C}$ & $\begin{array}{l}\text { Denaturation of the internal } \\
\text { proteins (coagulation) } \\
\text { Destruction of cell membranes } \\
\text { Coagulation of the extracellular } \\
\text { collagen } \\
\text { Devitalization }\end{array}$ \\
\hline $100^{\circ} \mathrm{C}$ & $\begin{array}{l}\text { Evaporation of cell liquid } \\
\text { Dessication/Vaporization } \\
\text { (depending on heating power) }\end{array}$ \\
\hline$>100^{\circ} \mathrm{C}$ & Carbonization \\
\hline
\end{tabular}

The changes described above also induce a changed electrical behaviour. This is important in electrosurgery, since electrical current is used to generate the heat. In general, at the $\mathrm{AC}$ frequency used in electrosurgery, the tissue behaves as an ohmic resistor to a good approximation. Figure 1 schematically shows the behaviour of the conductivity as a function of temperature. As the tissue gets heated, the conductivity increases in a reversible way due to the dissociation of electrolytes in the cellular liquid. Above $60^{\circ} \mathrm{C}$, the tissue gets coagulated, causing an additional and irreversible increase in conductivity due to the disruption of the cell membranes. At $100^{\circ} \mathrm{C}$, dessication of the tissue causes a strong fall in conductivity. Completely dessicated tissue is isolating [6].

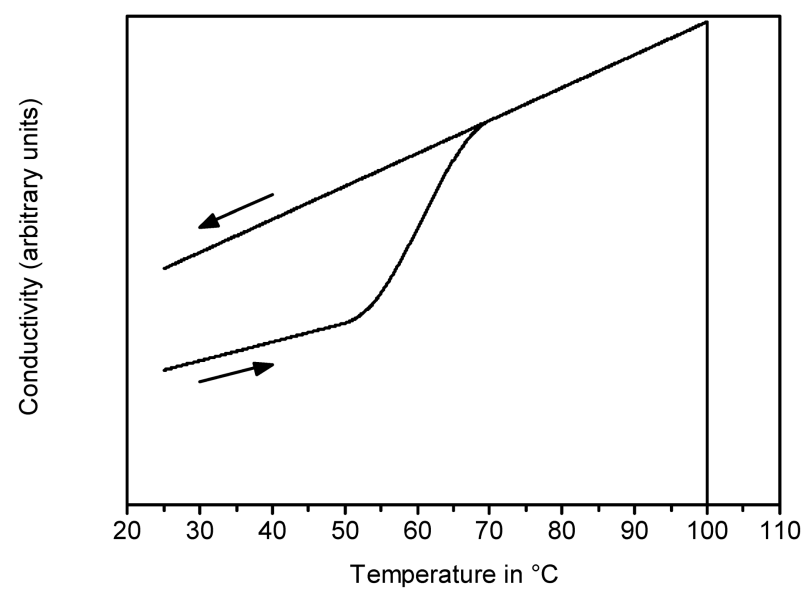

Figure 1: Schematical representation of the conductivity of tissue with changing temperature. The arrows indicate the direction of temperature change.

\subsection{Tissue heating via RF current}

In electrosurgery, the tissue is heated by electrical current via the Joule effect. The current is applied using two electrodes, respectively termed "active" and "neutral" electrode.

The power density being proportional to the square of the current density, the strongest heating occurs at a punctual contact between electrode and tissue. The power density then decreases with the fourth power of distance as the current penetrates deeper into the tissue.

The thermal effect occurs therefore at the active electrode (see Figure 2), which usually has a small contact area. For so-called monopolar applications, the neutral electrode is a plate with a large contact area, so that the current density is too low to generate a thermal effect. For bipolar applications, both electrodes are integrated in the application instrument.

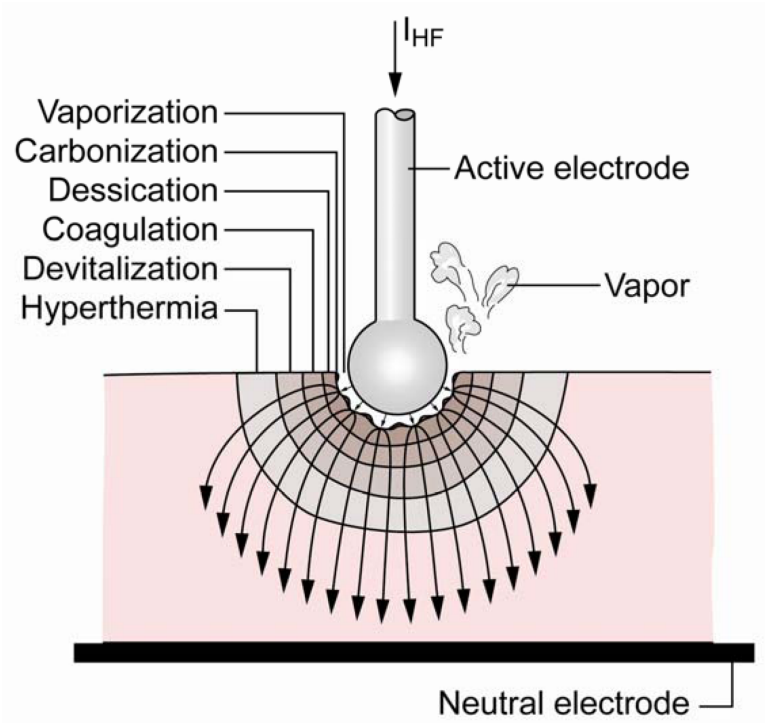

Figure 2: Schematic representation of thermal effects at the active electrode

The AC current has a frequency of at least $300 \mathrm{kHz}$ in order to avoid unwanted electrolysis in the tissue, or stimulation of nerve and muscle cells which occurs at lower frequencies. Electrosurgery is therefore also called "high-frequency (HF) surgery" or "radio-frequency (RF) surgery".

The thermal effect in the tissue depends mainly on the rate of heating and the attained temperature $T$, which in turn depend on the dissipated power and the exposure time. The effects in the tissue are commonly classified as coagulation (slower heating, $T<100^{\circ} \mathrm{C}$ ) and cut (quicker heating, $T>100^{\circ} \mathrm{C}$ ). The high current density required to achieve the violent heating necessary for the cutting effect is generated by microsparks between the electrode and the tissue. The term coagulation is used in electrosurgery to signify devitalization of tissue and stanching of bleeding (haemostasis) through desiccation of the cells and denaturation of proteins. To achieve the desired effect, e.g. to control the degree of coagulation 
at the borders of the cut, the current may be amplitude modulated.

\section{Argon Plasma in electrosurgery}

Argon plasma coagulation (APC) is a monopolar electrosurgical technique which uses argon discharges at atmospheric pressure to coagulate tissue. Argon was chosen because it is biochemically inert, has a low breakdown voltage and is relatively inexpensive.

Contrarily to devices such as the plasma needle [7], a current flow through the tissue is intended to generate the desired thermal effect, the plasma taking the role of the application electrode.

\subsection{Plasma generation}

The discharges are generated between the active electrode and the tissue to be treated (see Figure 3 and Figure 4). The electrode may be a tungsten wire with a diameter of several tenths of a millimetre, or a needle- or spatulashaped tip made of stainless steel. The distance between electrode and tissue is typically $2-10 \mathrm{~mm}$. The argon flows through a tube which surrounds the electrode. An AC voltage with an amplitude of typically $4 \mathrm{kV}$ and a frequency of typically $350 \mathrm{kHz}$ is used to ignite the discharge.

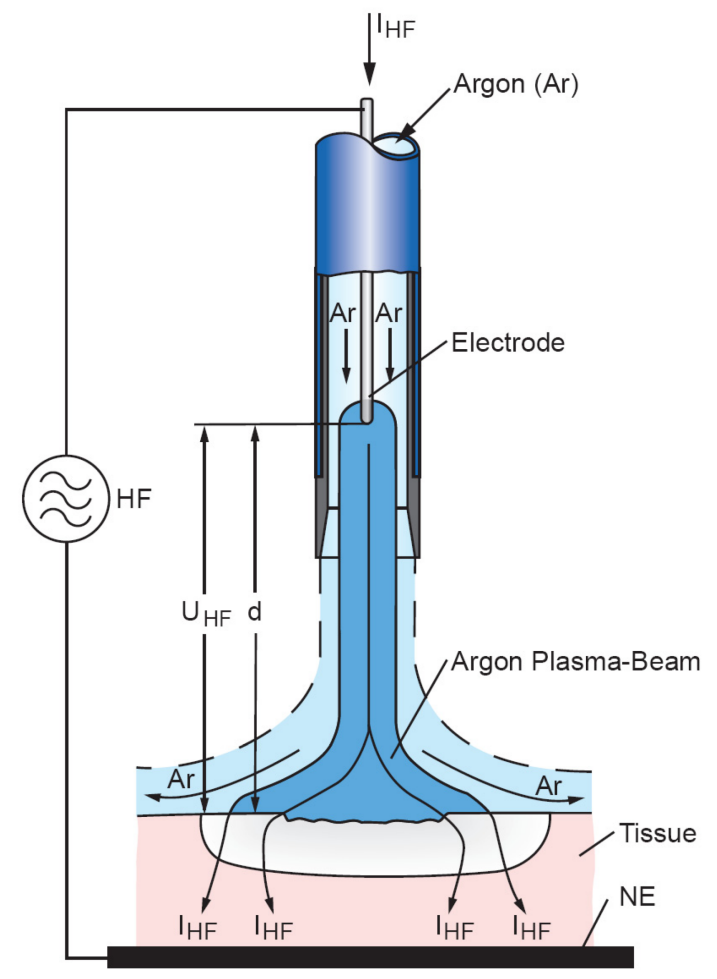

Figure 3: Schematic representation of a typical APC setup. The argon flows through a tube containing the electrode wire. The discharge is ignited by a $\mathrm{HF}$ voltage $\mathrm{U}_{\mathrm{HF}}$ between the wire end and the tissue. After breakdown, $\mathrm{HF}$ current $\mathrm{I}_{\mathrm{HF}}$ flows into the tissue, causing a coagulation effect, and back to the HF generator through the neutral electrode (NE).
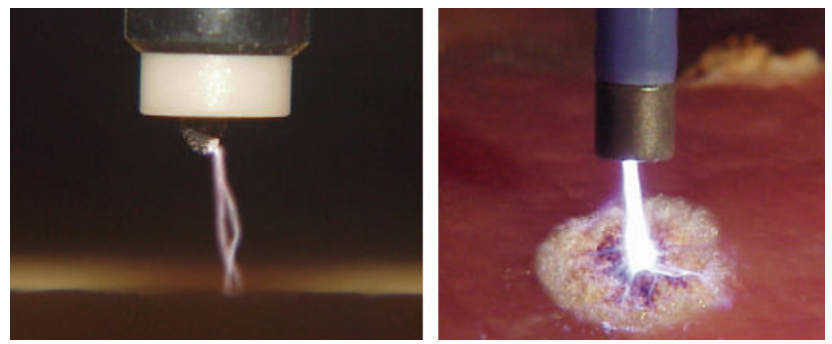

Figure 4: APC in action. The photographs are taken with different exposure times and show the end of an APC probe with two single sparks (left) resp. the resulting plasma beam (right) and a coagulated region on the tissue.

\subsection{Electrical characteristics and nature of the plasma}

Figure 5 shows a typical waveform of voltage and current for a burst of the ERBE VIO APC generator.

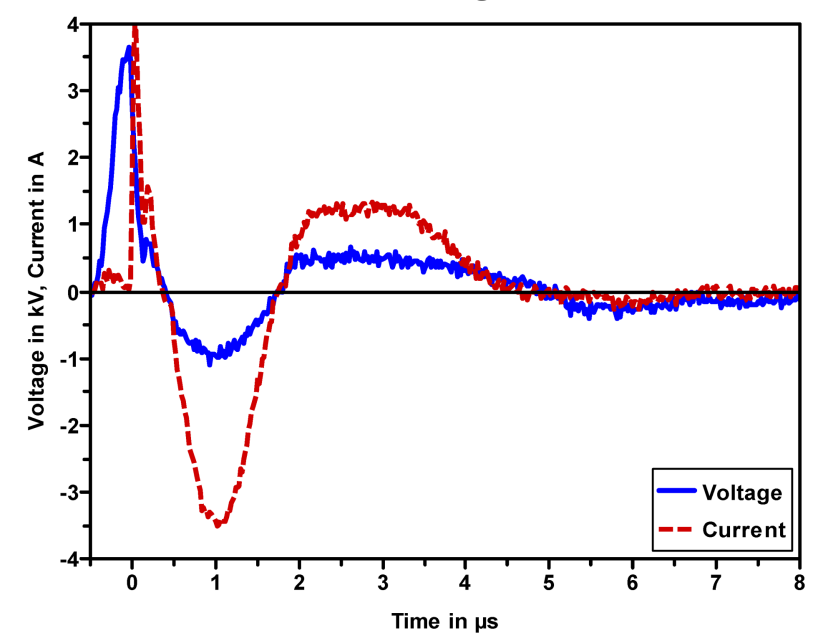

Figure 5: Typical waveforms for voltage and current for an APC burst, as generated by the ERBE VIO APC system

After breakdown, a current with a peak value of typically 2-5 A sets in and generates the effect in the tissue. The oscillation then gets damped due to the discharging of the oscillating circuit within the generator. These bursts are repeated with a rate of typically $20 \mathrm{kHz}$ (see Figure 4).

The relatively high current and the strong voltage breakdown seem to classify the APC discharge as a spark [8], [9], with the particularity that the plasma is maintained as long as the oscillating circuit is able to deliver enough current. It is likely that the current is not strong enough for thermal equilibrium within the plasma to be reached, since this would require currents of the order of $10 \mathrm{~A}$ [8]. The APC plasma seems therefore to be a cold, non-equilibrium plasma [10]. To our knowledge, it has not been investigated more closely to date. Therefore, physical details of the discharge process or the plasma-electrode and plasma-tissue interactions are not fully understood. 


\section{Medical applications}

Argon plasma coagulation is particularly well suited for superficial treatments since the penetration depth of the coagulation is limited to a few millimetres. The reason is that, since the tissue impedance increases when the tissue starts to dessicate after the coagulation process, the contact spot of the plasma on the tissue has the tendency to move to hydrated, possibly bleeding regions.

APC is used in nearly every surgical specialist area, such as general and visceral surgery, urology, gynaecology, gastroenterological [11] and bronchological endoscopy, and ENT. The major application fields are haemostasis and tissue devitalization, with a focus on endoscopic applications (see Figure 6).

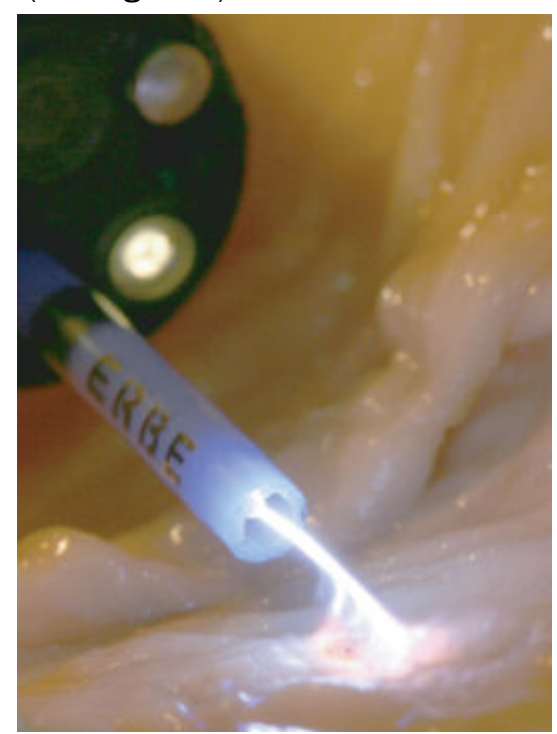

Figure 6: Endoscopic application of APC

For each application field, some examples will be cited in the following. More application examples are reported in [12] and [13].

\subsection{Stanching of bleeding (haemostasis)}

Bleeding (haemorrhages) may occur during operations, or due to ulcers, to injured or widened blood vessels (vascular lesions, vascular ectasia), varices, and tumours. Haemostasis during operations serves mainly to minimize blood loss. Using APC, relatively large surfaces can be efficiently treated.

An example for an operation where APC is used for haemostasis is the removal of tonsils (tonsillectomy) [14]. Other application fields include breast surgery and urology.

Examples for bleeding from other sources treated with APC are gastrointestinal vascular lesions [15], bleeding in the large intestine (colon) due to damage caused by radiotherapy (radiation proctritis, see Figure 7) [16], and heavy bleeding of an infected bladder (haemorrhagic cystitis) [17].

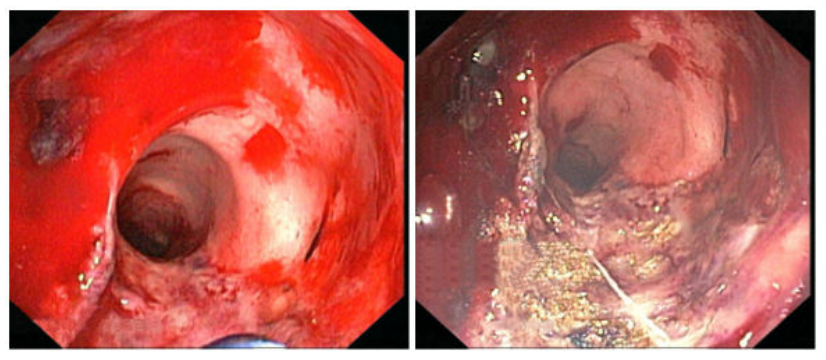

Figure 7: Bleeding in the colon due to radiation proctritis (left) before and (right) after treatment with APC. Reproduced with kind permission of A. Eickhoff, Klinikum Ludwigshafen, Germany

\subsection{Devitalization and tissue reduction}

Devitalization and shrinkage are often used for the treatment of tumours and obstructing tissue. In the case of tumours in an early state, the desired effect is to kill the cancerous tissue, which can then be removed mechanically where necessary. To treat obstructions by grown or swollen tissue, or by incurable tumours, the shrinkage effect of coagulation and dessication is used. If high power is applied, the tissue may also be carbonized or even vaporized.

Examples for devitalization and tissue reduction by APC are the treatment of overlarge nasal conchae (Figure 8) [18], and the minimally invasive treatment of tumours and metastases, e.g. in the respiratory or gastrointestinal tract. In skin surgery, APC is used to treat warts, actinic keratoses and haemangioma [19].

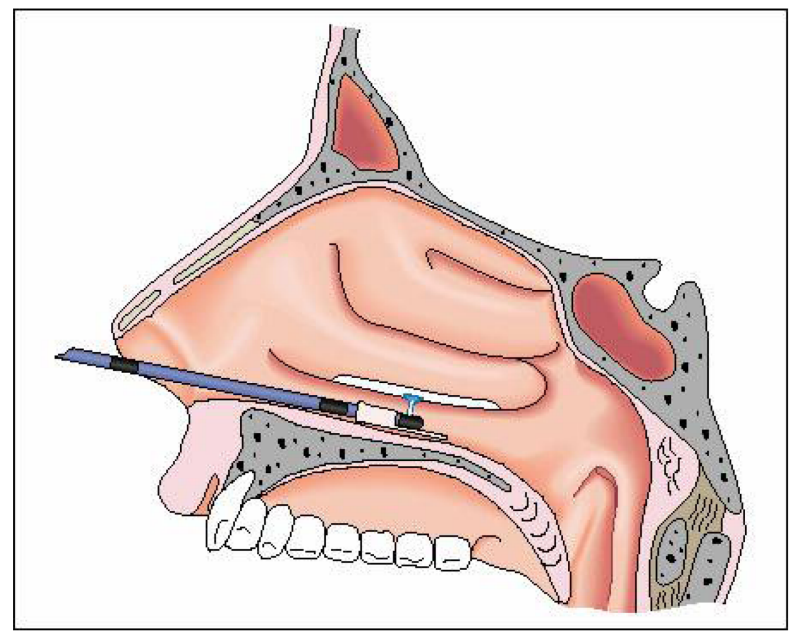

Figure 8: APC in the nasal cavity, where a probe with lateral outlet is used

\section{Summary}

In this article, the technique of Argon Plasma Coagulation (APC) has been presented. The plasma is used as application electrode for an alternating current in order to induce a thermal effect in biological tissue. APC is well established in medicine, especially for endoscopic and minimally invasive applications. However, the physical details of APC are not yet fully understood. 


\section{References}

1. Morrison Jr CF, inventor; Valleylab Inc., assignee. Electrosurgical method and apparatus for initiating an electrical discharge in an inert gas flow. United States patent 4040426. 1977.

2. Farin G, Grund KE. Technology of argon plasma coagulation with particular regard to endoscopic applications. Endoscop Surg Allied Technol. 1994;2:71-7.

3. Grund KE, Storek D, Farin G. Endoscopic argon plasma coagulation (APC): First clinical experiences in flexible endoscopy. Endoscop Surg Allied Technol. 1994;2:42-6.

4. Niemz MH. Laser-tissue interactions. Berlin: Springer; 2004.

5. Helfmann J. Thermal effects. In: Berlien HP, Müller GJ, editors. Applied Laser Medicine. Berlin: Springer; 2003. p. 111-7.

6. Stein T. Untersuchungen zur Dosimetrie der hochfrequenzstrominduzierten interstitiellen Thermotherapie in bipolarer Technik. Diss Berlin: Technische Univ; 2000.

7. Stoffels E, Kieft IE, Sladek REJ, van den Bedem LM, van der Laan EP, Steinbuch M. Plasma needle for in vivo medical treatment: recent developments and perspectives. Plasma Sources Sci Technol. 2006;15:S169-S180.

8. Raizer Yu P. Gas Discharge Physics. Berlin: Springer; 1991.

9. Bazelyan EM, Raizer Yu P. Spark Discharge. New York: CRC Press; 1998.

10. Fridman A, Chirokov A, Gutsol A. Non-thermal atmospheric pressure discharges. J Phys D: Appl Phys. 2005;38:R1-R24.

11. Ginsberg GG, Barkun AN, Bosco JJ, Burdick JS, Isenberg GA, Nakao NL, et al. The argon plasma coagulator. Gastrointest Endosc. 2002;55:807-10.

12. Raiser J, Zenker M. Argon plasma coagulation for open surgical and endoscopic applications: state of the art. J Phys D Appl Phys. 2006;39:3520-3.

13. Vargo JJ. Clinical applications of the argon plasma coagulator. Gastrointest Endosc. 2004;59:81-8.

14. Bergler W, Huber K, Hammerschmitt N, Hörmann K. Tonsillectomy with argon plasma coagulation: Evaluation of pain and hemorrhage. Laryngoscope. 2001;111:1423-9.
15. Kwan V, Bourke MJ, Williams SJ, Gillespie PE, Murray MA, Kaffes $\mathrm{AJ}$, et al. Argon plasma coagulation in the management of symptomatic gastrointestinal vasular lesions: experience in 100 consecutive patients with long-term follow-up. Am J Gastroenterol. 2006;101:58-63.

16. Villavicencio RT, Rex DK, Rahmani E. Efficacy and complications of argon plasma coagulation for hematochezia related to radiation proctopathy. Gastrointest Endosc. 2002;55:70-4.

17. Quinlan DM, Naslund MJ, Brendler CB. Application of argon beam coagulation in urological surgery. J Urol. 1992;147:410-2.

18. Bergler WF, Sadick H, Hammerschmitt N, Oulmi J, Hörmann K. Long-term results of inferior turbinate reduction with argon plasma coagulation. Laryngoscope. 2001;111:1593-8.

19. Brand CU, Blum A, Schlegel A, Farin G, Garbe C. Application of argon plasma coagulation in skin surgery. Dermatol. 1998;197:152-7.

\section{Corresponding author:}

Dr. rer. nat. Matthias Zenker

ERBE Elektromedizin GmbH, Waldhörnlestraße 17, 72072

Tübingen, Germany, Tel.: +49 (0)7071 755 226, Fax:

+49(0)70717555226

matthias.zenker@erbe-med.de

\section{Please cite as}

Zenker M. Argon plasma coagulation. GMS Krankenhaushyg Interdiszip. 2008;3(1):Doc15.

This article is freely available from

http://www.egms.de/en/journals/dgkh/2008-3/dgkh000113.shtml

\section{Copyright}

(C2008 Zenker. This is an Open Access article distributed under the terms of the Creative Commons Attribution License (http://creativecommons.org/licenses/by-nc-nd/3.0/deed.en). You are free: to Share - to copy, distribute and transmit the work, provided the original author and source are credited. 